\section{SOIL EROSION IN NEW ZEALAND}

\section{Soil Erosion in New Zealand}

A Geographic Reconnaissance. By Kenneth B. Cumberland. Pp. $\mathrm{xi}+227+43$ plates. (Wellington : Soil Conservation and Rivers Control Council, 1944.) n.p.

A FIVE-YEARS survey convinced the author A "that New Zealand, the youngest of the British Dominions, has a soil-erosion problem of greater significance in its relation to the future well-being of the country than has any one of the older members of the Commonwealth". He estimates that more than two thirds of the occupied area suffers from man-induced erosion.

The author approaches his subject from the geographical rather than from the agricultural point of view. Erosion in Now Zealand has a regional character, assuming distinct forms according to the climate, geology and related land use. Four erosion regions are distinguished in the North Island and four in the South Island. The most striking, and in the North Island one of the most prevalent, forms of erosion is the landslip which has devastated immense areas following the clearing of the bush. Landslip erosion is the consequence not only of human intervention, but also of the geological structure of the country. It seems to occur as a result of a slight disturbance in a delicately balanced equilibrium of physical and biological forces-most frequently on steep, deforested land that has gone down to grass. A secondary result of erosion that has caused widespread damage in New Zealand has been the silting-up of rivers and consequent floods. A somewhat unusual form of erosion that is prevalent in certain areas is called by the author "subcutaneous erosion", and results in the washing away of the impermeable subsoil while the permeable, grassed topsoil remains intact. Ultimately gullies and sinkholes are formed. The rapidity with which erosion has occurred in Now Zealand is due in no small measure to the extensive and repeated use of fire as a means of clearing the virgin bush.

Since New Zealand possesses few other major natural resources besides the fertility of the soil the problem of control is urgent. The author is more concerned with erosion than soil conservation, though the latter is discussed on general lines, and regional schemes based on adapting land use to the limitations imposed by the natural environment are suggested. Although the separate measures recommendedafforestation, improvement and control of pasture land, contour cultivation and strip-cropping-are those which are commonly advocated elsewhere, they require a different and unique synthesis into an integrated land-use programme, for the New Zealand climate is, on the whole, more maritime and less subject to extremes of temperature and humidity than the climates of most countries where erosion control has been scientifically studied. The author stresses the need for intensive research and State action on a large scale. In 1941 the Soil Conservation and Rivers Control Act became law, and a Soil Conservation and Rivers Control Council was set up with wide powers to carry out both conservation measures and research.

Sufficiently detailed accounts are given in a series of appendixes of the geological, climatic, vegetational and soil characteristics of the country to enable the reader who is unacquainted with New Zealand to get a clear picture of the geographical background of the problem. The book is illustrated with numerous beautiful and dramatic photographs. It should be read by everyone who is interested in this grave and widespread disease of the land.

G. V. JACKS.

\section{THE ELEMENTS RAGE}

The Elements Rage

By Frank W. Lane. Pp. xii $188+47$ plates. (London: Country Life, Ltd., 1945.) 10s. 6d. net.

THE more violent manifestations of Nature are of relatively infrequent occurrence, and so come into one individual's experience only at long intervals. If, then, we had to rely on the experience of one man only we should have a very inadequate picture of these abnormal phenomena. The author of the book under review has read and summarized a very great mass of literature dealing with hurricanes, tornadoes, waterspouts, hail, snow, lightning, meteorites, earthquakes and volcanoes, and from this has produced a readable book, in which a chapter is devoted to each of the nine topics enumerated above. To describe the book as readable is not to say that the reader will wish to devour it in one sitting. The rather overwhelming phenomena described can only be regarded as suitable for absorption in fairly small doses.

With the view of keeping the book free from error, so far as possible, the author had each chapter read over by at least one expert in the subject dealt with. The result has been to produce what is, on the whole, a reasonably accurate description of the phenomena, with an acceptable theoretical discussion in such parts of the book as call for theory. Here and there we find slips, which appear to indicate errors on the part of the experts, or failure of the author to listen to his experts. Thus on p. 2 we find the statement that "meteorologists define wind speed as the velocity with which the wind would carry a very light object, such as a fragment of thistledown, in a perfectly open situation, thirty-three feet above the ground". This is inaccurate, since wind speed can be defined at any height above the ground, and the wind at $33 \mathrm{ft}$. (10 metres) is a convenient specification of the surface wind.

But apart from a few unimportant slips, the treatment of the subject is clear and simple, and the book is well illustrated with photographs of tornadoes, waterspouts, hailstones, meteorite craters, earthquakes, volcanic eruptions, and of some of the dreadful damage produced by these phenomena. Among the most interesting parts of the book must be reckoned the four pages that describe the new volcano Paricutin in Mexico, which appeared in February 1943, the first new volcano to appear on the American continent in nearly two centuries. Paricutin appears to outdo Vesuvius in violence, being distinguished by its habit of spouting a hail of large fragments of lava thousands of feet into the air, and so endangering all forms of life in its immediate neighbourhood. A photograph of Paricutin in eruption appears as the frontispiece to the book, showing the magnificent plumes of smoke which tower high above the summit.

Mr. Lane has performed a very useful service to all who are interested in the violent manifestations of Nature, by writing a coherent account of these, and collecting into one volume the known facts relating to them. The book deserves to be widely read.
D. BRUNT. 